\title{
Marmorkrebs (Procambarus fallax f. virginalis) are the most popular crayfish in the North American pet trade
}

\author{
Z. Faulkes ${ }^{(1), \star}$ \\ Received January 15, 2015 \\ Revised May 30, 2015 \\ Accepted June 25, 2015
}

Key-words:
Marbled
crayfish,
pet trade,
Marmorkrebs,
Cambarellus

\section{RÉSUMÉ}

\section{ABSTRACT}

Introductions of non-native crayfish around the world are increasingly tied to the distribution, sale, and eventual release of pet crayfish. As part of risk assessment for the introduction of non-native crayfish in North America, I monitored the sale of crayfish on an auction website that specializes in aquatic pets and aquarium supplies for a year. Three species accounted for the majority of sales: the parthenogenetic crayfish, Marmorkrebs (Procambarus fallax f. virginalis), the Cajun dwarf crayfish (Cambarellus shufeldtii), and the orange morph of the endangered Mexican dwarf crayfish (Cambarellus patzcuarensis). Almost half of individual crayfish sold (48.5\%) were Marmorkrebs, which is more than twice as many as C. shufeldtii, the second most commonly sold species. The Louisiana red swamp crayfish (Procambarus clarkii) was often offered for auction, but was bought much less often than the other three species. About $11 \%$ of P. clarkii auctions were successful, while more than $45 \%$ of auctions were successful for the other three. Four Cherax species were the only crayfish sold online whose native range was outside North America. Neither Marmorkrebs nor the orange morph of $C$. patzcuarensis can be collected regularly from natural habitats in North America, suggesting that most crayfish sold online in North America are obtained from existing stocks in the pet trade, rather than being collected from natural habitats.

Les écrevisses marbrées (Procambarus fallax f. virginalis) sont les écrevisses les plus populaires dans le commerce des animaux en Amérique du Nord

Mots-clés :

Écrevisse marbrée, commerce animaux, Marmorkrebs, Cambarellus
Les introductions d'écrevisses non indigènes dans le monde entier sont de plus en plus liées à la distribution, la vente, et le relâcher éventuel des écrevisses achetées comme « animaux de compagnie ». Dans le cadre de l'évaluation des risques pour l'introduction d'écrevisses non indigènes en Amérique du Nord, je surveillais pendant une année la vente des écrevisses sur un site de vente aux enchères qui se spécialise dans les animaux aquatiques et les fournitures d'aquarium. Trois espèces ont représenté la majorité des ventes : l'écrevisse parthénogénétique, Marmorkrebs (Procambarus fallax f. virginalis), l'écrevisse naine (Cambarellus

(1) Department of Biology, The University of Texas-Pan American, 1201 W. University Drive, Edinburg, Texas, 78539, USA

* Corresponding author: zen.faulkes@utrgv.edu 
shufeldtii), et la forme orange des écrevisses naines mexicaines en danger (Cambarellus patzcuarensis). Plus de deux fois plus de Marmorkrebs ont été vendues que de $C$. shufeldtii, la deuxième espèce la plus couramment vendue. L'écrevisse de Louisiane (Procambarus clarkii) était souvent offerte aux enchères, mais a été achetée beaucoup moins souvent que les trois autres espèces. Environ $11 \%$ des ventes de $P$. clarkii ont abouti, alors que plus de $45 \%$ des ventes aux enchères ont réussi pour les trois autres. Quatre espèces de Cherax étaient les seules écrevisses vendues en ligne dont l'aire de répartition originelle est extérieure à l'Amérique du Nord. Ni marmorkrebs ni la forme orange de C. patzcuarensis ne peuvent être collectées régulièrement dans les habitats naturels en Amérique du Nord, ce qui suggère que la plupart des écrevisses vendues en ligne en Amérique du Nord sont obtenues à partir des stocks existants dans le commerce des animaux, plutôt que d'être collectées dans les habitats naturels.

\section{INTRODUCTION}

Increasingly, understanding the ecology of crayfish requires extensive knowledge of human interactions with them. For example, human population density and economic development of areas is correlated with exotic species introductions (Gallardo, 2014; Gallardo and Aldridge, 2013; Perdikaris et al., 2012), including crayfish (Chucholl, 2014).

The pet trade has been responsible for many introductions of non-native species (Chang et al., 2009; Duggan, 2010; Keller and Lodge, 2009; Strecker et al., 2011), and is likely the major driver of introductions of non-indigenous crayfish in several countries (Chucholl, 2013; Soes and Koese, 2010). The scale of the trade in pets, particularly aquatic animals, has been difficult to estimate (Rhyne et al., 2012), but online sale and trade websites can provide estimates of the risk of introduction of non-indigenous species (Kikillus et al., 2012).

A few studies have begun characterizing the trade in crayfish in some countries. In Germany, 123 crayfish species were available for sale, of which 105 species were North American natives (Chucholl, 2013), compared to about 30 species recorded in the Czech Republic (Patoka et al., 2014a; Patoka et al., 2015), nine species in Turkey (Turkmen and Karadal, 2012), eight species in Greece (Papavlasopoulou et al., 2014), and one in Brazil (Loureiro et al., 2015). The pet trade in crayfish in North America has not been studied in depth, even though it is a large potential market for crayfish pets. Approximately $10 \%$ of North American homes have aquaria (Chapman et al., 1997). Previously, I studied the online discussion of one crayfish species, Marmorkrebs (Procambarus fallax f. virginalis), showing they were readily available and frequently sold in North America (Faulkes, 2013). However, there was no way to compare the availability and price of Marmorkrebs to other crayfish on the market. In Germany, the Netherlands, and the Czech Republic, Marmorkrebs are very common pet crayfish (Chucholl, 2013; Patoka et al., 2014a; Patoka et al., 2014b; Patoka et al., 2015; Soes and Koese, 2010), but they are not available in Greece (Papavlasopoulou et al., 2014) or Turkey (Turkmen and Karadal, 2012).

While much of the research on the sale of crayfish as pets has focused on the possibility of the introduction of exotic species (Chucholl, 2013; Papavlasopoulou et al., 2014; Soes and Koese, 2010), how those species are initially sourced can also be a concern (Calado et al., 2003; Lukhaup, 2015). North America is home to more crayfish species than anywhere else in the world (Crandall and Buhay, 2008; Richman et al., 2015), but about half of North American species pose some sort of conservation concern (Taylor et al., 2007). It is possible that within North America, collectors could harm native North American crayfish species by exploiting local populations for selling at auction. Similarly, pet hobbyists are often interested in owning species that have some sort of novelty factor; the vast majority of North American aquarium fish, for example, are not native species (Strecker et al., 2011). Thus, it is not clear whether the most popular crayfish sold in North American would originate from North America. For example, many North American crayfish species are imported to the Czech Republic from 
Asian countries (Patoka et al., 2015). Here, I examine which crayfish species are most often bought and sold in the online pet trade in North America.

\section{MATERIALS AND METHODS}

I monitored the website Aquabid (http://www.aquabid.com) from 1 January 2013 to 31 December 2013. This site was selected because it appeared repeatedly in previous research on the pet trade in Marmorkrebs (Faulkes, 2010, 2013), and because its completed auction listings were more easily interpreted than eBay, the other main sales site appearing in previous research (Faulkes, 2010, 2013). For example, Aquabid does not allow users the ability to sell multiple copies of the same items in one auction listing, and does not allow buyers to pay different prices depending on whether the buyer will "buy it now" or allow the auction to run its course. Thus, the auction process used by Aquabid significantly reduces ambiguity in regard to prices paid.

Using Aquabid's "Advanced search" page (http://www.aquabid.com/cgi-bin/auction/search. cgi), I searched for the word "crayfish" using the "Keyword - all items" option (default) in the category "Freshwater -> Invertebrates", and checking the "Search Completed listings" option. Although crayfish could be listed for auction by other names (e.g., "crawfish", "crawdads", "lobsters"), there is no reason to think that auctions listed under "crayfish", or in other sections of the website, would not be representative of the larger sample of crayfish auctions. The search typically retrieved listings at least a month old, and the site was searched multiple times a week.

For each listing, I recorded the crayfish species, the auction URL, the initial asking price, the number of crayfish being sold, a low and high shipping cost, the date the auction closed, the number of bids, the price that the animals were sold at, the Aquabid user name of the buyer, and the Aquabid name, city, and state of the seller. All prices were recorded, and are reported in this paper, in US dollars. Each auction listing was converted to a PDF for archival purposes. Although crayfish size affects price (Faulkes, 2013; Patoka et al., 2015), it was not recorded as a variable here, because it was not consistently listed by sellers, and it is not clear that different sellers estimate size the same way (e.g., carapace length versus body length including the claws versus body length excluding the claws).

Many sellers used scientific species names in their auction listings, and the species identification was that given by the seller, which may or may not be accurate (Keller and Lodge, 2009). When sellers described crayfish using a common name, I searched for whether that name appeared in Taylor et al. (2007), and used the scientific name from that list. For some auctions, the descriptions in the listing did not allow a tentative species identification, and were counted as unknown.

To test that the patterns seen in Aquabid were similar to those at other North American auction sites online, I checked eBay (http://www.ebay.com) from 1 to 30 June 2013. Unless otherwise specified, results refer to the Aquabid listings only.

Locations of sellers were located in Google Mapmaker (http://www.google.com/mapmaker) and plotted using Indiemapper (http://indiemapper.com). The conservation status of species was determined by consulting the International Union for Conservation of Nature (IUCN) Red List of Threatened Species (http://www.iucnredlist.org). Each IUCN assessment is authored separately, and cited individually here.

\section{RESULTS}

In total, 472 Aquabid auctions by 53 sellers resulted in the sale of 954 individual crayfish, at a total cost of US $\$ 4338.81$ (excluding shipping costs).

Twenty-four crayfish species, plus one hybrid (of Procambarus clarkii and P. alleni), were listed for sale in online auctions (Table I). Thirteen species were sold only on Aquabid, ten species 


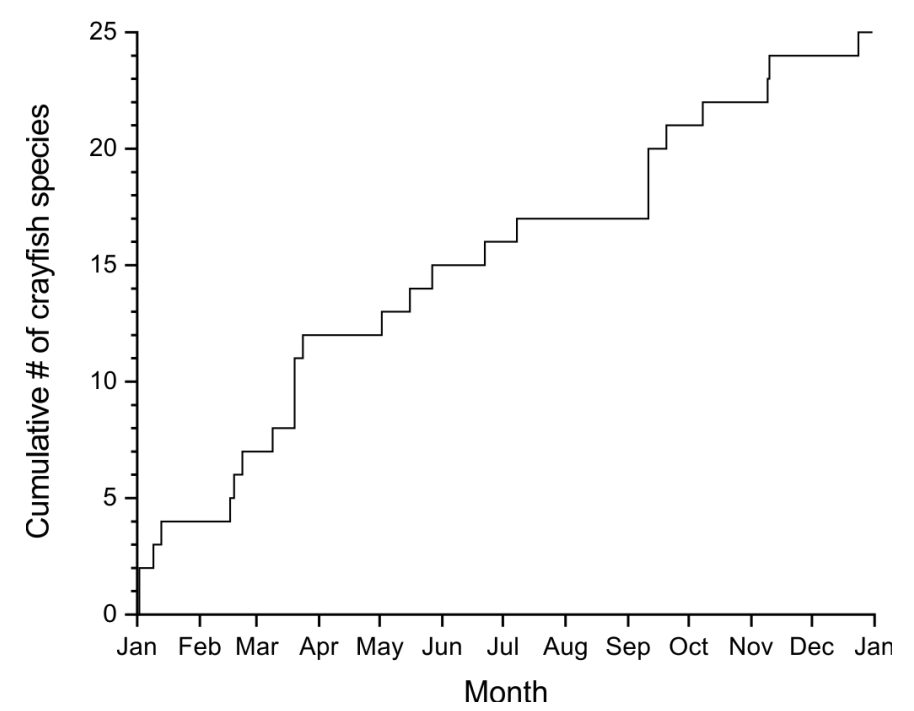

Figure 1

Cumulative count of number of crayfish species listed in auctions over the year 2013.

were sold on both Aquabid and eBay, and one species, Cherax holthuisi, appeared on eBay only. Most of the species were native to North America, except for four Cherax species, which originate from Australia and New Guinea. New species continued to be listed for the first time throughout the year (Figure 1).

Six species listed in auctions are already been established in natural ecosystems outside their native ranges (Table I), according to Gherardi (2013). Sixteen are listed as species of least concern by the IUCN Red List, but of those, three are predicted to become threatened in the future (Larson and Olden, 2010). Three species have insufficient data to assess endangered species status, three are under various levels of threat, and one has not been assessed. The species listed by IUCN as being of the greatest concern, with an "Endangered" rating, is $C$. patzcuarensis, one of the most widely bought and sold species, although the colour morph differentiates those sold as pets from the wild population.

Four species made up $84.5 \%$ of Aquabid auction listings (Table II): Marmorkrebs (Procambarus fallax f. virginalis); Cajun dwarf crayfish (Cambarellus shufeldtii); Mexican dwarf crayfish (Cambarellus patzcuarensis), always with an orange colour morph (often abbreviated as "CPO" in listings, presumably for "C. patzcuarensis orange"); and Louisiana red swamp crayfish (Procambarus clarkii). These were the only four species to be listed in more than five successful auctions on Aquabid. These same four species were also the most commonly listed species on eBay (Table III), with Marmorkrebs being offered for sale on eBay about three times more often than the next most commonly offered species.

Marmorkrebs were included in 39\% more auctions than $P$. clarkii, the next most commonly listed species (Table I). Marmorkrebs accounted for almost half (48.5\%) of individual crayfish sold (Figure 2). The number of individual Marmorkrebs sold, and the number of unique buyers of Marmorkrebs, were both more than double those of $C$. shufeldtii, the second highest ranked species in those measures (Table I). More individual C. patzcuarensis were put up for auction than any other species. Several auctions listed $100 \mathrm{C}$. patzcuarensis individuals for sale at once, and one auction offered 3001 individuals. This latter auction for 3001 individuals was also notable because it was the only seller from outside North America, namely Indonesia.

Over $45 \%$ of auctions that included P. fallax f. virginalis (47.5\%), C. patzcuarensis (51.4\%), and C. shufeldtii (48.7\%) were successful (Figure 3A). Procambarus clarkii, though listed more often than C. patzcuarensis and C. shufeldtii, was purchased less often. Only $11.3 \%$ of auctions including $P$. clarkii were successful. The average prices paid for these four species differed significantly (Figure 3B: one way ANOVA, $F_{3,157}=17.38, p<0.01$ ), with $P$. fallax f. virginalis 


\section{Table I}

List of crayfish species traded as pets online in North America. Country of origin from Fetzner (2005); predicted conservation status from Larson and Olden (2010); non-indigenous status from Gherardi (2013).

\begin{tabular}{|c|c|c|c|c|c|}
\hline Family & Species & $\begin{array}{l}\text { Country } \\
\text { of } \\
\text { origin }\end{array}$ & IUCN status & \begin{tabular}{|c|} 
Predicted \\
conservation \\
status
\end{tabular} & $\begin{array}{c}\text { Non- } \\
\text { indigenous }\end{array}$ \\
\hline \multirow[t]{4}{*}{ Parastacidae } & Cherax destructor & Australia & $\begin{array}{l}\text { Vulnerable } \\
\text { (Crandall, } \\
\text { 1996) }\end{array}$ & & Yes \\
\hline & Cherax holthuisi & $\begin{array}{l}\text { Indonesia } \\
\text { (West New } \\
\text { Guinea) }\end{array}$ & $\begin{array}{l}\text { Data deficient } \\
\text { (Austin, } \\
\text { 2010a) }\end{array}$ & & \\
\hline & Cherax peknyi & $\begin{array}{l}\text { Papua } \\
\text { New } \\
\text { Guinea }\end{array}$ & $\begin{array}{l}\text { Data deficient } \\
\text { (Austin, } \\
2010 \mathrm{~b} \text { ) }\end{array}$ & & \\
\hline & $\begin{array}{c}\text { Cherax } \\
\text { quadricarinatus }\end{array}$ & Australia & $\begin{array}{c}\text { Least concern } \\
\text { (Austin et al., 2010) }\end{array}$ & & Yes \\
\hline \multirow[t]{17}{*}{ Cambaridae } & $\begin{array}{l}\text { Cambarellus } \\
\text { diminutus }\end{array}$ & United States & $\begin{array}{l}\text { Data deficient } \\
\text { (Adams and } \\
\text { Jones, 2010) }\end{array}$ & & \\
\hline & $\begin{array}{l}\text { Cambarellus } \\
\text { montezumae }\end{array}$ & Mexico & $\begin{array}{c}\text { Least concern } \\
\text { (Alvarez et al., 2010a) }\end{array}$ & & \\
\hline & $\begin{array}{l}\text { Cambarellus } \\
\text { patzcuarensis }\end{array}$ & Mexico & $\begin{array}{l}\text { Endangered (Alvarez } \\
\text { et al., 2010b) }\end{array}$ & & \\
\hline & $\begin{array}{l}\text { Cambarellus } \\
\text { shufeldtii }\end{array}$ & United States & $\begin{array}{c}\text { Least concern } \\
\text { (Alvarez et al., 2010c) }\end{array}$ & Imperiled & \\
\hline & $\begin{array}{l}\text { Cambarus } \\
\text { bartonii } \\
\text { bartonii }\end{array}$ & $\begin{array}{c}\text { Canada, } \\
\text { United States }\end{array}$ & $\begin{array}{l}\text { Least concern } \\
\text { (Cordeiro et al., } \\
2010 \text { a) } \\
\end{array}$ & Secure & \\
\hline & $\begin{array}{l}\text { Cambarus } \\
\text { diogenes }\end{array}$ & United States & $\begin{array}{c}\text { Least concern } \\
\text { (Cordeiro et al., 2010b) }\end{array}$ & Secure & \\
\hline & $\begin{array}{l}\text { Fallicambarus } \\
\text { fodiens }\end{array}$ & \begin{tabular}{|c|} 
Canada, \\
United States
\end{tabular} & $\begin{array}{l}\text { Least concern } \\
\text { (Crandall, 2010a) }\end{array}$ & Imperiled & \\
\hline & $\begin{array}{l}\text { Faxonella } \\
\text { clypeata }\end{array}$ & United States & $\begin{array}{l}\text { Least concern } \\
\text { (Crandall, 2010b) }\end{array}$ & Imperiled & \\
\hline & $\begin{array}{l}\text { Orconectes } \\
\text { acares }\end{array}$ & United States & $\begin{array}{c}\text { Least concern } \\
\text { (Schuster et al., 2010) }\end{array}$ & & \\
\hline & $\begin{array}{l}\text { Orconectes } \\
\text { immunis }\end{array}$ & $\begin{array}{c}\text { Canada, } \\
\text { United States }\end{array}$ & $\begin{array}{c}\text { Least concern } \\
\text { (Adams et al., 2010a) }\end{array}$ & Extraregional & Yes \\
\hline & $\begin{array}{c}\text { Orconectes } \\
\text { neglectus }\end{array}$ & United States & $\begin{array}{c}\text { Least concern } \\
\text { (Adams et al., 2010b) }\end{array}$ & \begin{tabular}{|c|} 
Extraregional/ \\
Extralimital \\
\end{tabular} & Yes \\
\hline & $\begin{array}{l}\text { Orconectes } \\
\text { rusticus }\end{array}$ & \begin{tabular}{|c|} 
Canada, \\
United States
\end{tabular} & $\begin{array}{c}\text { Least concern } \\
\text { (Adams et al., 2010c) }\end{array}$ & Extraregional & Yes \\
\hline & $\begin{array}{c}\text { Procambarus } \\
\text { alleni }\end{array}$ & United States & $\begin{array}{l}\text { Least concern } \\
\text { (Crandall, 2010c) }\end{array}$ & & \\
\hline & $\begin{array}{c}\text { Procambarus alleni/ } \\
\text { Procambarus clarkii } \\
\text { hybrids }\end{array}$ & N/A & $\mathrm{N} / \mathrm{A}$ & & \\
\hline & $\begin{array}{c}\text { Procambarus } \\
\text { clarkii }\end{array}$ & $\begin{array}{c}\text { Mexico, } \\
\text { United States }\end{array}$ & $\begin{array}{c}\text { Least concern } \\
\text { (Crandall, 2010d) }\end{array}$ & Extraregional & Yes \\
\hline & $\begin{array}{l}\text { Procambarus } \\
\text { fallax } \mathrm{f} . \\
\text { virginalis }\end{array}$ & \begin{tabular}{|c|} 
Unknown \\
(sexual form: \\
United States)
\end{tabular} & $\begin{array}{l}\text { Least concern } \\
\text { (sexual form) } \\
\text { (Crandall, 2010e) }\end{array}$ & & Yes \\
\hline & $\begin{array}{l}\text { Procambarus } \\
\text { natchitochae }\end{array}$ & United States & $\begin{array}{l}\text { Least concern } \\
\text { (Crandall, 2010f) }\end{array}$ & & \\
\hline
\end{tabular}


Table I

Continued.

\begin{tabular}{|c|c|c|c|c|c|}
\hline Family & Species & $\begin{array}{l}\text { Country } \\
\text { of } \\
\text { origin }\end{array}$ & IUCN status & $\begin{array}{c}\text { Predicted } \\
\text { conservation } \\
\text { status }\end{array}$ & $\begin{array}{l}\text { Non- } \\
\text { indigenous }\end{array}$ \\
\hline & $\begin{array}{l}\text { Procambarus } \\
\text { paeninsulanus }\end{array}$ & United States & $\begin{array}{c}\text { Vulnerable } \\
\text { Least concern } \\
\text { (Crandall, 2010g) }\end{array}$ & & \\
\hline & $\begin{array}{l}\text { Procambarus } \\
\text { pictus }\end{array}$ & United States & $\begin{array}{c}\text { Near threatened } \\
\text { (Moler and Crandall, 2010) }\end{array}$ & & \\
\hline & $\begin{array}{c}\text { Procambarus } \\
\text { tulanei }\end{array}$ & United States & $\begin{array}{l}\text { Least concern } \\
\text { (Crandall, 2010h) }\end{array}$ & & \\
\hline & $\begin{array}{c}\text { Procambarus } \\
\text { vasquezae }\end{array}$ & Mexico & Not yet assessed & & \\
\hline
\end{tabular}

Table II

Summary of crayfish auctions on Aquabid in 2013, sorted alphabetically by species. The numbers of auctions for each species do not equal the total number of auctions (472) because some auctions sold several species in mixed lots.

\begin{tabular}{|c|c|c|c|c|c|c|}
\hline Species & $\begin{array}{l}\text { Number } \\
\text { of auctions }\end{array}$ & $\begin{array}{l}\text { Percent } \\
\text { of auctions } \\
\text { successful }\end{array}$ & $\begin{array}{l}\text { Number } \\
\text { of sellers }\end{array}$ & $\begin{array}{l}\text { Number } \\
\text { of buyers }\end{array}$ & $\begin{array}{c}\text { Number } \\
\text { of crayfish } \\
\text { offered }\end{array}$ & $\begin{array}{c}\text { Number } \\
\text { of crayfish } \\
\text { sold }\end{array}$ \\
\hline $\begin{array}{l}\text { Cambarellus } \\
\text { diminutus }\end{array}$ & 1 & $100 \%$ & 1 & 1 & 2 & 2 \\
\hline $\begin{array}{l}\text { Cambarellus } \\
\text { montezumae }\end{array}$ & 1 & $0 \%$ & 1 & 0 & 5 & 0 \\
\hline $\begin{array}{l}\text { Cambarellus } \\
\text { patzcuarensis }\end{array}$ & 70 & $51.43 \%$ & 8 & 30 & 4171 & 133 \\
\hline $\begin{array}{l}\text { Cambarellus } \\
\text { shufeldtii }\end{array}$ & 76 & $48.68 \%$ & 5 & 31 & 454 & 212 \\
\hline $\begin{array}{l}\text { Cambarus bartonii } \\
\text { bartonii }\end{array}$ & 1 & $0 \%$ & 1 & 0 & 1 & 0 \\
\hline Cambarus diogenes & 1 & $0 \%$ & 1 & 0 & 1 & 0 \\
\hline Cherax destructor & 3 & $0 \%$ & 2 & 0 & 4 & 0 \\
\hline Cherax peknyi & 2 & $0 \%$ & 1 & 0 & 2 & 0 \\
\hline $\begin{array}{l}\text { Cherax } \\
\text { quadricarinatus }\end{array}$ & 3 & $33.33 \%$ & 2 & 1 & 3 & 2 \\
\hline Fallicambarus fodiens & 1 & $100 \%$ & 1 & 1 & 2 & 2 \\
\hline Faxonella clypeata & 2 & $100 \%$ & 1 & 2 & 15 & 15 \\
\hline Orconectes acares & 3 & $66.67 \%$ & 1 & 2 & 6 & 4 \\
\hline Orconectes immunis & 5 & $40 \%$ & 1 & 2 & 9 & 2 \\
\hline Orconectes neglectus & 2 & $50 \%$ & 1 & 1 & 4 & 2 \\
\hline Procambarus alleni & 16 & $25 \%$ & 4 & 3 & 131 & 14 \\
\hline $\begin{array}{l}\text { Procambarus alleni/ } \\
\text { P. clarkii hybrid }\end{array}$ & 21 & $9.52 \%$ & 1 & 2 & 179 & 6 \\
\hline $\begin{array}{l}\text { Procambarus } \\
\text { clarkii }\end{array}$ & 115 & $11.3 \%$ & 11 & 13 & 421 & 57 \\
\hline $\begin{array}{l}\text { Procambarus fallax } \\
\text { f. virginalis }\end{array}$ & 160 & $47.5 \%$ & 25 & 66 & 1089 & 476 \\
\hline $\begin{array}{l}\text { Procambarus } \\
\text { natchitochae }\end{array}$ & 2 & $0 \%$ & 1 & 0 & 4 & 0 \\
\hline $\begin{array}{l}\text { Procambarus } \\
\text { paeninsulanus }\end{array}$ & 6 & $66.67 \%$ & 1 & 4 & 36 & 24 \\
\hline $\begin{array}{l}\text { Procambarus } \\
\text { pictus }\end{array}$ & 1 & $0 \%$ & 1 & 0 & 1 & 0 \\
\hline $\begin{array}{l}\text { Procambarus } \\
\text { tulanei }\end{array}$ & 2 & $100 \%$ & 2 & 2 & 4 & 4 \\
\hline $\begin{array}{l}\text { Procambarus } \\
\text { vasquezae }\end{array}$ & 2 & $0 \%$ & 1 & 0 & 6 & 0 \\
\hline Unknown & 16 & $43.75 \%$ & 7 & 7 & 42 & 27 \\
\hline
\end{tabular}




\section{Table III}

Summary of crayfish available on eBay in July 2013. The numbers of auctions for each species do not total the number of auctions in the database because of single auctions selling several species in mixed lots.

\begin{tabular}{|l|l|}
\hline Species & Number of auctions \\
\hline Cambarellus patzcuarensis & 23 \\
\hline Cambarellus shufeldtii & 23 \\
\hline Cherax destructor & 3 \\
\hline Cherax holthuisi & 4 \\
\hline Orconectes immunis & 1 \\
\hline Orconectes virilis & 3 \\
\hline Procambarus alleni & 9 \\
\hline Procambarus clarkii & 34 \\
\hline Procambarus fallax & 1 \\
\hline Procambarus fallax f. virginalis & 99 \\
\hline Procambarus paeninsulanus & 6 \\
\hline Unknown & 39 \\
\hline
\end{tabular}

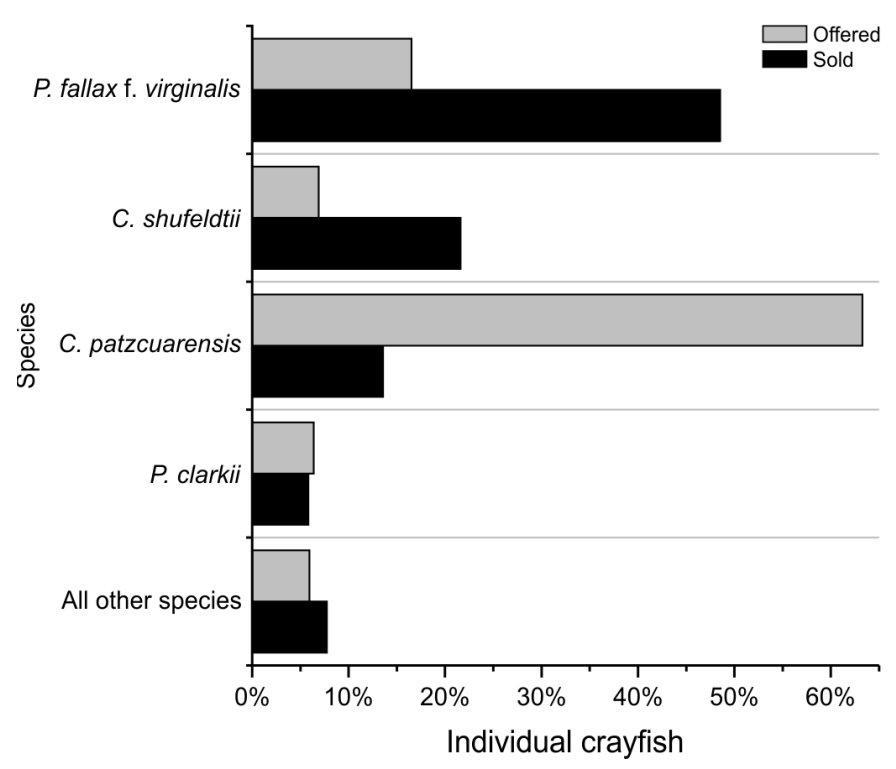

\section{Figure 2}

The proportion of the market for each crayfish species in terms of number of individual crayfish offered for sale (gray bars) and sold (black bars).

and C. shufeldtii being significantly cheaper than C. patzcuarensis, which was in turn significantly cheaper than $P$. clarkii (Tukey's post-hoc test).

Procambarus clarkii is normally dark red in nature (hence its common name, Louisiana red swamp crayfish). A wide variety of colour morphs were readily available for sale, including blue, white, orange, "royal", "ghost", "neon red", and "blue and pink". The asking prices for these morphs differed significantly (Figure 4: one way ANOVA, $F_{4,65}=4.24, p<0.01$ ), with blue morphs alone commanding a higher asking price (Tukey's post-hoc test).

Combining Aquabid and eBay, sellers came from 24 American states and the District of Columbia, one Canadian province (Figure 5), and Indonesia (one auction for C. patzcuarensis; not shown in Figure 5). Five out of 54 sellers accounted for $50.85 \%$ of Aquabid auction listings. Sellers tended to specialize in a small number of species. Only two sellers offered more than five different species, with one of those offering more than half of the species found online ( 15 of 25 species or hybrids).

Some sellers appeared to be engaging in illegal activities by auctioning crayfish. Three sellers listed Arizona as their location, which is a jurisdiction that prohibits the sale of crayfish (Faulkes, 2013). Maryland prohibits the sale of some crayfish species (Faulkes, 2013), and 

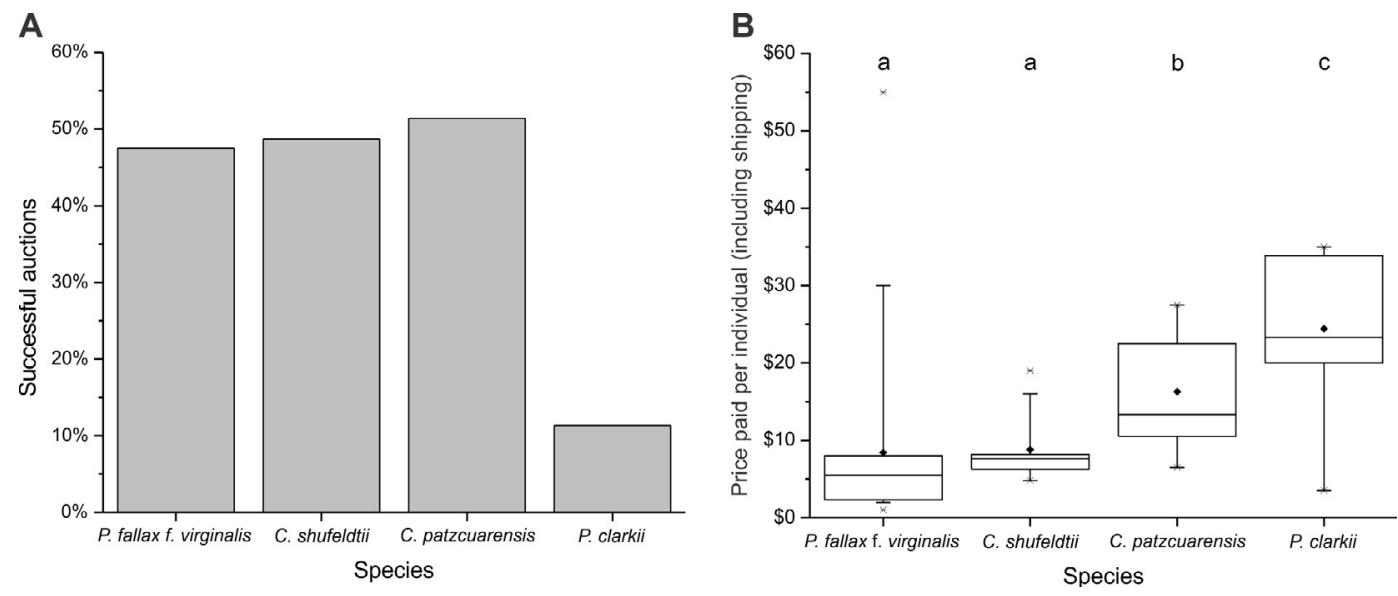

Figure 3

Comparison of four main crayfish species sold at auction in terms of popularity at auction (A) and price (B). Prices paid per individual crayfish include shipping costs; when multiple prices for shipping were given, the highest was used. Prices in US dollars. Crayfish from mixed lot auctions with multiple species were excluded. Species sharing a letter above their box do not significantly differ from each other. Dot $=$ mean, line $=$ median, box $=50 \%$ of data, whiskers $=95 \%$ of data, cross $=$ minimum and maximum.

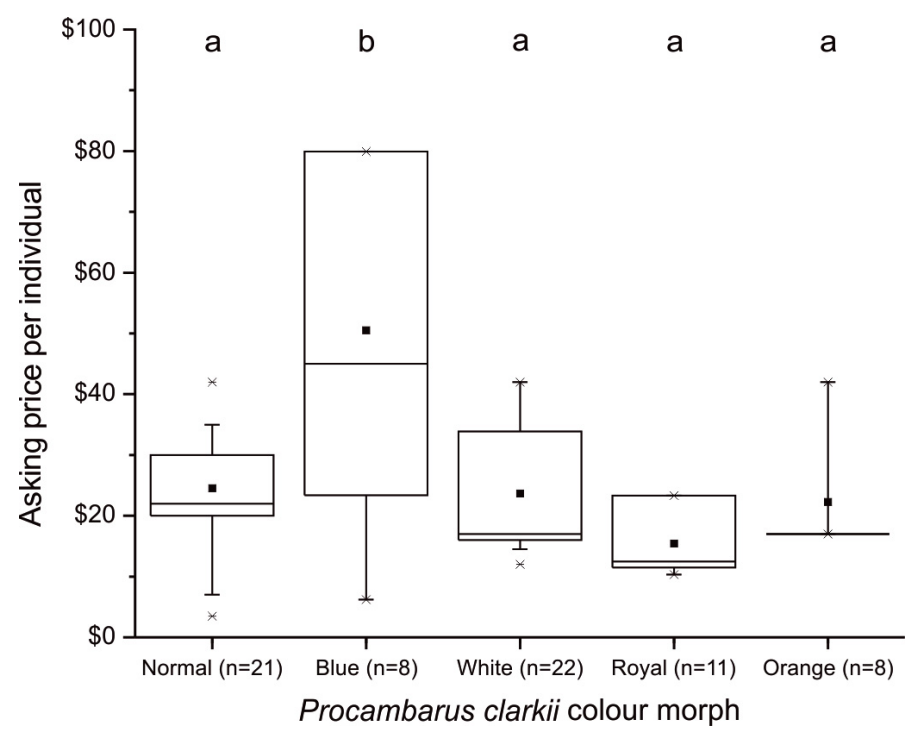

Figure 4

Comparison of asking price of different P. clarkii colour morphs offered at auction. Asking prices given per individual crayfish plus shipping costs; when multiple prices for shipping were given, the highest was used. Prices in US dollars. Crayfish from mixed lot auctions with multiple species were excluded. Morphs sharing a letter above their box do not significantly differ from each other. Dot = mean, line = median, box $=50 \%$ of data, whiskers $=95 \%$ of data, cross $=$ minimum and maximum.

is considering a ban on the sale of all species (Maryland Department of Natural Resources, 2014). The one seller in Maryland was the second most prolific seller on Aquabid, accounting for $12.23 \%$ of listings. It appears the same seller was also active on eBay, with a slightly different user name, based on the location and texts of advertisements. The seller offered twice as many different species for sale as any other seller on Aquabid, and offered species that are illegal to sell in Maryland, including Marmorkrebs and Orconectes rusticus.

There was some seasonal variation in online auction activity (Figure 6). The number of sellers, buyers, and auction listings all dipped in August, though there was no clear trend in the percentage of successful auctions. 


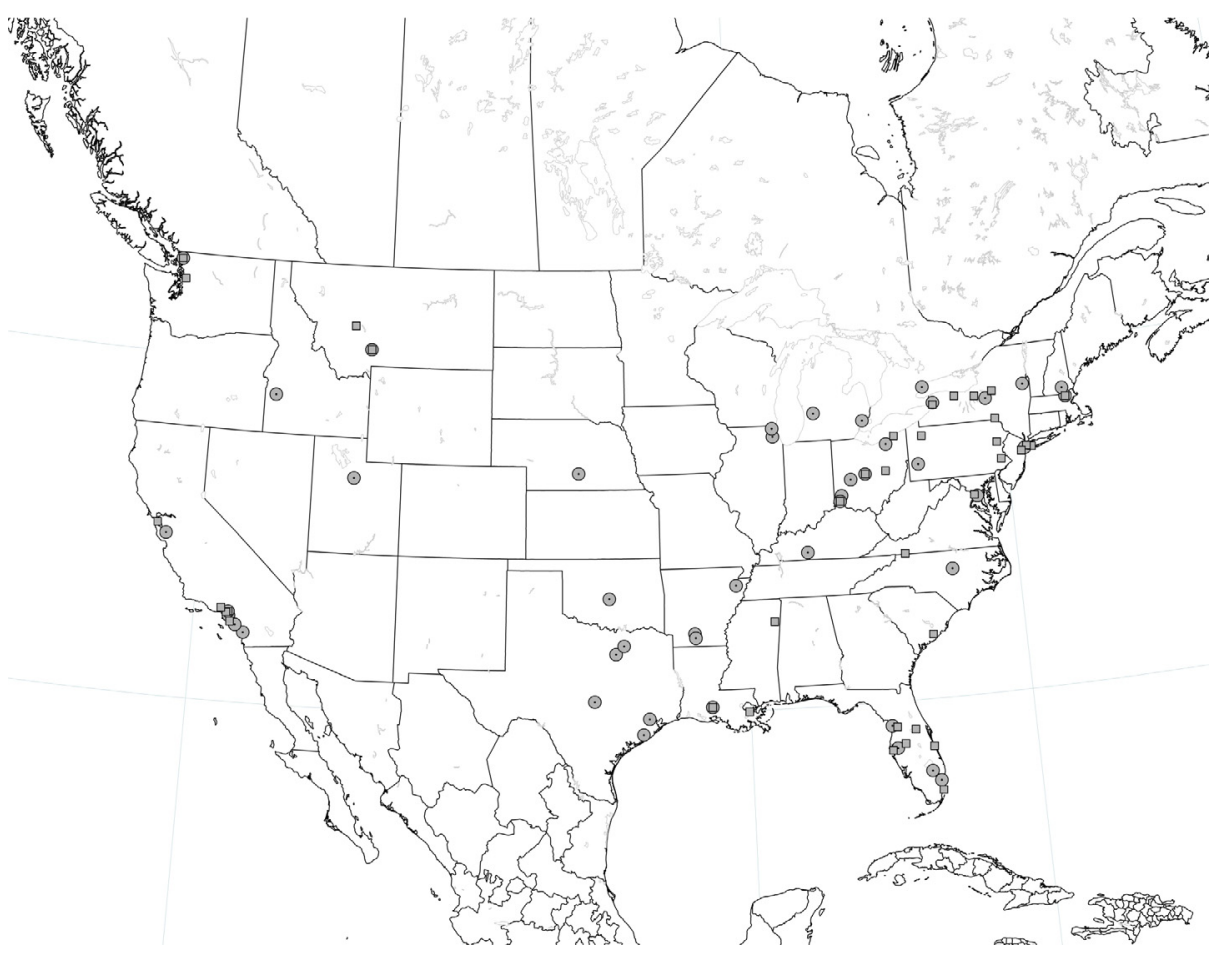

\section{Figure 5}

Location of sellers listing auctions of crayfish on Aquabid (circles) and eBay (squares).
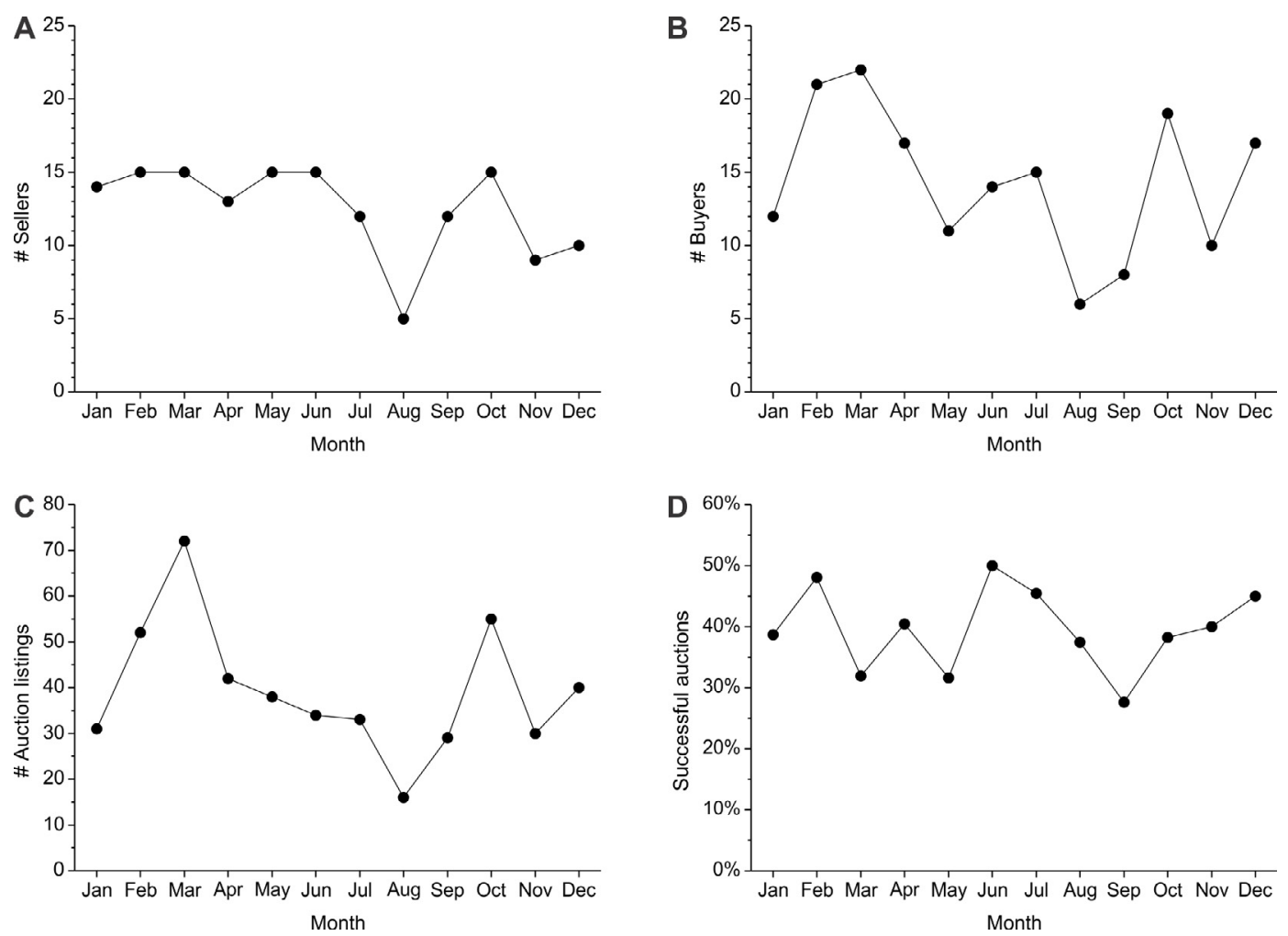

Figure 6

Number of people selling crayfish (A), people buying crayfish (B), number of auctions of crayfish (C), and percentage of successful auctions (D). 


\section{DISCUSSION}

Twenty-four crayfish species, plus one hybrid and some unknown species, were found in North American online auctions between two websites. This paucity of species stands in sharp contrast to over a hundred species available for sale in Germany (Chucholl, 2013), but roughly in line with about 30 species available in the Czech Republic (Patoka et al., 2014b) and the Netherlands (Soes and Koese, 2010), and substantially higher than the eight recorded in the pet trade in Greece (Papavlasopoulou et al., 2014) and one in Brazil (Loureiro et al., 2015). Three species account for most $(83.7 \%)$ of the online crayfish trade in North America: Marmorkrebs (Procambarus fallax f. virginalis), the Cajun dwarf crayfish (Cambarellus shufeldtii), and the Mexican dwarf crayfish (Cambarellus patzcuarensis). A fourth species, Louisiana red swamp crayfish (Procambarus clarkii), is often auctioned, but less often sold than the other three, perhaps because it is on average more expensive than the other three species. Procambarus clarkii is perhaps the most widely distributed species in the global pet trade, and is listed as common in every country where the crayfish trade has been examined (Germany: Chucholl, 2013, Czech Republic: Patoka et al., 2014b, the Netherlands: Soes and Koese, 2010, Greece: Papavlasopoulou et al., 2014, Brazil: Loureiro et al., 2015, Turkey: Turkmen and Karadal, 2012). As shown here, availability does not necessarily translate into large numbers of sales. For example, Cherax peknyi, C. quadricarinatus, and P. clarkii are listed as "very common" imports in the Czech market (Patoka et al., 2015), but the list of the most commonly kept crayfish species kept in garden ponds is slightly different, consisting of $P$. fallax $\mathrm{f}$. virginalis, C. patzcuarensis, and P. clarkii (Patoka et al., 2014b).

The number of new crayfish species available in the North American pet trade showed no obvious signs of leveling off during the study period, so while continued monitoring of the online pet trade would likely detect more species available for sale, any additional crayfish species would make only tiny contributions to the total in online trade. The majority of species sold in North America are North American species. While species from Australia and New Guinea are occasionally available, none are as widely distributed as some Cherax species appear to be in European markets (Chucholl, 2013; Papavlasopoulou et al., 2014; Patoka et al., 2014a; Patoka et al., 2015; Soes and Koese, 2010; Turkmen and Karadal, 2012).

By every measure, Marmorkrebs are the most common crayfish species in the North American pet trade. They are the most commonly offered at auction. They are the most commonly bought, as measured by number of individuals sold and number of unique buyers. They are tied with C. patzcuarensis as the cheapest crayfish on the market. Previously, I estimated the price for Marmorkrebs at US $\$ 5.00$ (Faulkes, 2013). This study refines that estimate by including shipping costs, and only calculating prices from successful auctions, which should more accurately reflect what people are willing to pay for one Marmorkrebs: US\$8.42, on average, higher than the price of $€ 5$ in Germany (Chucholl, 2013) and $€ 2.59$ for large individuals in the Czech Republic (Patoka et al., 2015). Marmorkrebs were known in the German pet trade in the 1990s, but were not officially introduced to the scientific literature until 2003 (Scholtz et al., 2003). They were probably introduced to the North American pet trade in the early 2000s (Faulkes, 2010), meaning Marmorkrebs have gone from "unknown" to "abundant" in the North American pet trade in the space of about a decade. They have received intense interest as a potentially invasive species (Chucholl et al., 2012; Faulkes, 2010; Feria and Faulkes, 2011) because of their parthenogenetic mode of reproduction (Scholtz et al., 2003), which means that single individuals can establish populations. This unusual method of reproduction probably also contributes to their spread in the pet trade. Parthenogenesis has a novelty value, increasing their attractiveness to buy. Parthenogenesis also makes it a virtual guarantee that a Marmorkrebs owner will have to decide what to do with tens to hundreds of crayfish offspring.

The Mexican dwarf crayfish, C. patzcuarensis, is readily available in most countries where the crayfish pet trade has been examined (Chucholl, 2013; Papavlasopoulou et al., 2014; Patoka et al., 2014b; Turkmen and Karadal, 2012). The ubiquity of C. patzcuarensis is interesting because of the difference between its wild population and that in the pet trade. This species' natural population is restricted to a small region in Mexico, and is endangered (Alvarez et al., 
2010b), and wild individuals are brown. This species in the pet trade is abundant (one auction offered 3001 individuals), and invariably bright orange. Apparently all the orange individuals in the pet trade can be traced back to a single individual pet owner in the Netherlands (Dost, 2013). Apart from the original species description and work on epibionts (Mayén-Estrada and Aladro-Lubel, 2001a; Mayén-Estrada and Aladro-Lubel, 2000, 2001b), little technical research has been performed on C. patzcuarensis. If the wild population is extirpated, it seems unlikely that the population from the pet trade could be used to reintroduce the species. The bright orange colour of $C$. patzcuarensis sold in the pet trade may be highly visible to predators, and the individuals in the pet trade may be highly inbred.

Since popularity in the pet trade is correlated with risk of release and introduction (Duggan et al., 2006; Kikillus et al., 2012), the lack of basic biological information on many of the crayfish species available in the North American pet trade is worrying. Marmorkrebs is an emerging model organism (Vogt, 2008, 2011), but its interactions with other species in natural habitats, particularly with other crayfish, are still mostly unknown (but see Chucholl and Pfeiffer, 2010; Jimenez and Faulkes, 2011). Of the top four crayfish species in the North American pet trade, $P$. clarkii is the only crayfish species whose biology has been extensively studied. But while the biology of $P$. clarkii may be well known, the biology of $P$. clarkii/P. alleni hybrids is not. Procambarus clarkii is renowned as a successful non-indigenous invasive species (Ellis et al., 2012; Holdich et al., 2009; Moreira et al., 2014), so it is conceivable that $P$. clarkii/P. alleni hybrids may have characteristics that might also make the hybrids successful at establishing themselves if they are released into natural ecosystems.

Because North America is the biodiversity hotspot for crayfish (Richman et al., 2015), it is conceivable that sellers would collect and sell native crayfish species from nearby lakes and streams. Patoka et al. (2014b) noted that about $5 \%$ of crayfish keepers surveyed in the Czech Republic admitted to collecting crayfish locally, but this is probably an underestimate, given that catching crayfish was illegal in that jurisdiction. The evidence from the four main species sold in this study suggests that most people selling crayfish initially get those crayfish from within the pet trade, rather than collecting individuals from local native populations or other sources (e.g., crayfish sold for human consumption in grocery stores; Patoka et al., 2014b). Marmorkrebs has not been reported in natural habitats in North America (Faulkes, 2010), although the sexually reproducing form, $P$. fallax, is a North American native. Similarly, the bright colour morphs of $C$. patzcuarensis and $P$. clarkii are rare mutations that are not often reported in wild populations (Black and Huner, 1980; Dost, 2013). This suggests that in North America, there is currently little interest in collecting "rare" North American crayfish species from aquarium hobbyists (Soes and Koese, 2010), which provides little incentive for collectors to trap and sell potentially threatened crayfish species.

Knowing the number of buyers can help assess the risk of release. About $10 \%$ of US homes keep freshwater fish (Chapman et al., 1997), although there appear to be no estimates of how many households keep crayfish. When aquarium owners are surveyed, $6.4-6.98 \%$ say that have released live fish into natural water bodies in the past (Gertzen et al., 2008; Strecker et al., 2011), although there are no data on the average number of fish released by an owner. Based on sales from the main website examined here (Aquabid), and assuming that the rate of release of crayfish is similar to that of fish, about four crayfish buyers per year might be expected to release their purchased Marmorkrebs, and about two people per year might release C. patzcuarensis and C. shufeldtii. Further, one individual owner could release many individual crayfish. The ease of breeding these crayfish species, particularly Marmorkrebs, may increase the probability of owners releasing crayfish they bought or bred, although "rapid reproduction" is rarely given as a reason for releasing fish (Gertzen et al., 2008). Nevertheless, considering that there are other popular sales websites that sell crayfish, such as eBay, Craig's List (http://craigslist.org), and Kijiji (http://kijiji.ca) (Faulkes, 2013), as well as trades and sales through personal contacts (Faulkes, 2010), the propagule pressure for these three species is not negligible. Risk assessment has been started for Marmorkrebs, with the development of quantitative species distribution models for North America (Feria and Faulkes, 2011) and FI-ISK assessments (Chucholl, 2013; Patoka et al., 2014a). Similarly, initial risk assessment for 
Cambarellus species suggests they are at relatively low risk of becoming invasive (Chucholl, 2013; Gherardi et al., 2011).

The popularity of these crayfish species in online trade could result in them being picked up and distributed by larger businesses, which would put these species within the reach of more casual pet owners. There are several reports of Marmorkrebs being sold in local pet stores in North America (Faulkes, 2013), but there are no available reports of Marmorkrebs being distributed by larger business franchises (i.e., national or multinational businesses). How national pet chains determine what pets to sell is not transparent. For example, I asked customer support at the pet store chain PetCo (http://www.petco.com) about how it decides what new pets to sell in its stores. A Customer Relations Coordinator replied, "We are unable to provide interviews or details about company strategies or programs".

\section{ACKNOWLEDGEMENTS}

I thank two anonymous reviewers for their constructive comments.

\section{REFERENCES}

Adams S. and Jones R.L., 2010. Cambarellus diminutus. The IUCN Red List of Threatened Species, http://www.iucnredlist.org/details/3670/0.

Adams S., Schuster G.A. and Taylor C.A., 2010a. Orconectes immunis. The IUCN Red List of Threatened Species, http://www.iucnredlist.org/details/153925/0.

Adams S., Schuster G.A. and Taylor C.A., 2010b. Orconectes neglectus. The IUCN Red List of Threatened Species, http://www.iucnredlist.org/details/153807/0.

Adams S., Schuster G.A. and Taylor C.A., 2010c. Orconectes rusticus. The IUCN Red List of Threatened Species, http://www.iucnredlist.org/details/153835/0.

Alvarez F., López-Mejía M. and Pedraza Lara C., 2010a. Cambarellus montezumae. The IUCN Red List of Threatened Species, http://www.iucnredlist.org/details/153816/0.

Alvarez F., López-Mejía M. and Pedraza Lara C., 2010b. Cambarellus patzcuarensis. The IUCN Red List of Threatened Species, http://www.iucnredlist.org/details/153802/0.

Alvarez F., López-Mejía M., Pedraza Lara C. and DiStefano R.J., 2010c. Cambarellus shufeldtii. The IUCN Red List of Threatened Species, http://www.iucnredlist.org/details/154008/0.

Austin C.M., 2010a. Cherax holthuisi. The IUCN Red List of Threatened Species, http://www.iucnredlist. org/details/153651/0.

Austin C.M., 2010b. Cherax peknyi. The IUCN Red List of Threatened Species, http://www.iucnredlist. org/details/165921/0.

Austin C.M., Jones C. and Wingfield M., 2010. Cherax quadricarinatus. The IUCN Red List of Threatened Species, http://www.iucnredlist.org/details/4621/0.

Black J.B. and Huner J.V., 1980. Genetics of the red swamp crawfish, Procambarus clarkii (Girard): state-of-the-art. Proc. World Mariculture Soc., 11, 535-543.

Calado R., Lin J., Rhyne A.L., Araújo R. and Narciso L., 2003. Marine ornamental decapods-popular, pricey, and poorly studied. J. Crust. Biol., 23, 963-973.

Chang A., Grossman J., Spezio T., Weiskel H., Blum J., Burt J., Muir A., Piovia-Scott J., Veblen K. and Grosholz E., 2009. Tackling aquatic invasions: risks and opportunities for the aquarium fish industry. Biol. Invasions, 11, 773-785.

Chapman F.A., Fitz-Coy S.A., Thunberg E.M. and Adams C.M., 1997. United States of America trade in ornamental fish. J. World Aquacult. Soc., 28, 1-10.

Chucholl C., 2013. Invaders for sale: trade and determinants of introduction of ornamental freshwater crayfish. Biol. Invasions, 15, 125-141.

Chucholl C., 2014. Predicting the risk of introduction and establishment of an exotic aquarium animal in Europe: insights from one decade of Marmorkrebs (Crustacea, Astacida, Cambaridae) releases. Manage. Biol. Invasions, 5, 309-318. 
Chucholl C. and Pfeiffer M., 2010. First evidence for an established Marmorkrebs (Decapoda, Astacida, Cambaridae) population in Southwestern Germany, in syntopic occurrence with Orconectes limosus (Rafinesque, 1817). Aquat. Invasions, 5, 405-412.

Chucholl C., Morawetz K. and Groß H., 2012. The clones are coming - strong increase in Marmorkrebs [Procambarus fallax (Hagen, 1870) f. virginalis] records from Europe. Aquat. Invasions, 7, 511-519.

Cordeiro J., Hamr P., Skelton C. and Thoma R.F., 2010a. Cambarus bartonii. The IUCN Red List of Threatened Species, http://www.iucnredlist.org/details/153748/0.

Cordeiro J., Jones T. and Thoma R.F., 2010b. Cambarus diogenes. The IUCN Red List of Threatened Species, http://www.iucnredlist.org/details/153814/0.

Crandall K.A., 1996. Cherax destructor. The IUCN Red List of Threatened Species, http://www. iucnredlist.org/details/4622/0.

Crandall K.A., 2010a. Fallicambarus fodiens. The IUCN Red List of Threatened Species, http://www. iucnredlist.org/details/153747/0.

Crandall K.A., 2010b. Faxonella clypeata. The IUCN Red List of Threatened Species, http://www. iucnredlist.org/details/153949/0.

Crandall K.A., 2010c. Procambarus alleni. The IUCN Red List of Threatened Species, http://www. iucnredlist.org/details/153828/0.

Crandall K.A., 2010d. Procambarus clarkii. The IUCN Red List of Threatened Species, http://www. iucnredlist.org/details/153877/0.

Crandall K.A., 2010e. Procambarus fallax. The IUCN Red List of Threatened Species, http://www. iucnredlist.org/details/153961/0.

Crandall K.A., 2010f. Procambarus natchitochae. The IUCN Red List of Threatened Species, http://www. iucnredlist.org/details/153996/0.

Crandall K.A., 2010g. Procambarus paeninsulanus. The IUCN Red List of Threatened Species, http:// www.iucnredlist.org/details/153841/0.

Crandall K.A., 2010h. Procambarus tulanei. The IUCN Red List of Threatened Species, http://www. iucnredlist.org/details/153775/0.

Crandall K. and Buhay J., 2008. Global diversity of crayfish (Astacidae, Cambaridae, and ParastacidaeDecapoda) in freshwater. Hydrobiologia, 595, 295-301.

Dost U., 2013. The orange dwarf crayfish. Tropical Fish Hobbyist, April 2013, 64-67.

Duggan I., 2010. The freshwater aquarium trade as a vector for incidental invertebrate fauna. Biol. Invasions, 12, 3757-3770.

Duggan I., Rixon C. and Maclsaac H., 2006. Popularity and propagule pressure: determinants of introduction and establishment of aquarium fish. Biol. Invasions, 8, 377-382.

Ellis A., Jackson M.C., Jennings I., England J. and Phillips R., 2012. Present distribution and future spread of Louisiana red swamp crayfish Procambarus clarkii (Crustacea, Decapoda, Astacida, Cambaridae) in Britain: Implications for conservation of native species and habitats. Knowl. Manag. Aquat. Ecosyst., 406, 05.

Faulkes Z., 2010. The spread of the parthenogenetic marbled crayfish, Marmorkrebs (Procambarus sp.), in the North American pet trade. Aquat. Invasions, 5, 447-450.

Faulkes Z., 2013. How much is that crayfish in the window? Online monitoring of Marmorkrebs, Procambarus fallax f. virginalis (Hagen, 1870) in the North American pet trade. Freshwater Crayfish, 19, 39-44.

Feria T.P. and Faulkes Z., 2011. Forecasting the distribution of Marmorkrebs, a parthenogenetic crayfish with high invasive potential, in Madagascar, Europe, and North America. Aquat. Invasions, 6, 55-67.

Fetzner Jr. J.W., 2005. Crayfish Taxonomy Browser. Carnegie Museum of Natural History, http://iz. carnegiemnh.org/crayfish/NewAstacidea/infraorder.asp?io=Astacidea.

Gallardo B., 2014. Europe's top 10 invasive species: relative importance of climatic, habitat and socioeconomic factors. Ethol. Ecol. Evol., 26, 130-151.

Gallardo B. and Aldridge D.C., 2013. The 'dirty dozen': socio-economic factors amplify the invasion potential of 12 high-risk aquatic invasive species in Great Britain and Ireland. J. Appl. Ecol., 50, 757-766. 
Gertzen E., Familiar O. and Leung B., 2008. Quantifying invasion pathways: fish introductions from the aquarium trade. Can. J. Fish. Aquat. Sci., 65, 1265-1273.

Gherardi F., 2013. Crayfish as global invaders: Distribution impact on ecosystem services and management options. Freshwater Crayfish, 19, 177-187.

Gherardi F., Aquiloni L., Diéguez-Uribeondo J. and Tricarico E., 2011. Managing invasive crayfish: is there a hope? Aquat. Sci., 73, 185-200.

Holdich D.M., Reynolds J.D., Souty-Grosset C. and Sibley P.J., 2009. A review of the ever increasing threat to European crayfish from non-indigenous crayfish species. Knowl. Manag. Aquat. Ecosyst., 394-395, 11.

Jimenez S.A. and Faulkes Z., 2011. Can the parthenogenetic marbled crayfish Marmorkrebs compete with other crayfish species in fights? J. Ethol., 29, 115-120.

Keller R.P. and Lodge D.M., 2009. Species invasions from commerce in live aquatic organisms: Problems and possible solutions. BioScience, 57, 428-436.

Kikillus K.H., Hare K. and Hartley S., 2012. Online trading tools as a method of estimating propagule pressure via the pet-release pathway. Biol. Invasions, 14, 2657-2664.

Larson E.R. and Olden J.D., 2010. Latent extinction and invasion risk of crayfishes in the Southeastern United States. Conserv. Biol., 24, 1099-1110.

Loureiro T.G., Anastácio P.M., Bueno S.L.S., Araujo P.B., Souty-Grosset C. and Almerão M.P., 2015. Distribution, introduction pathway, and invasion risk analysis of the North American crayfish (Decapoda: Cambaridae) in southeast Brazil. J. Crust. Biol., 35, 88-96.

Lukhaup C., 2015. Cherax (Astaconephrops) pulcher, a new species of freshwater crayfish (Crustacea, Decapoda, Parastacidae) from the Kepala Burung (Vogelkop) Peninsula, Irian Jaya (West Papua), Indonesia. ZooKeys, 502, 1-10.

Maryland Department of Natural Resources, 2014. Maryland scoping of possible regulations. Maryland Department of Natural Resources, http://dnr2.maryland.gov/fisheries/Pages/regulations/scoping. aspx.

Mayén-Estrada R. and Aladro-Lubel M.A., 2000. First record of Lagenophrys dennisi (Ciliophora: Peritrichia) on the exoskeleton of crayfish Cambarellus patzcuarensis. J. Eukaryotic Microbiol., 47, 57-61.

Mayén-Estrada R. and Aladro-Lubel M., 2001a. Epibiont peritrichids (Ciliophora: Peritrichida: Epistylididae) on the crayfish Cambarellus patzcuarensis in Lake Pátzcuaro, Michoacán, Mexico. J. Crust. Biol., 21, 426-434.

Mayén-Estrada R. and Aladro-Lubel M.A., 2001b. Distribution and prevalence of 15 species of epibiont peritrich ciliates on the crayfish Cambarellus patzcuarensis Villalobos, 1943 in Lake Pátzcuaro, Michoacán, Mexico. Crustaceana, 74, 1213-1224.

Moler P. and Crandall K.A., 2010. Procambarus pictus. The IUCN Red List of Threatened Species, http:// www.iucnredlist.org/details/18213/0.

Moreira F., Ascensão F., Capinha C., Rodrigues D., Segurado P., Santos-Reis M. and Rebelo R., 2014. Modelling the risk of invasion by the red-swamp crayfish (Procambarus clarkii): incorporating local variables to better inform management decisions. Biol. Invasions, 17, 273-285.

Papavlasopoulou I., Perdikaris C., Vardakas L. and Paschos I., 2014. Enemy at the gates: introduction potential of non-indigenous freshwater crayfish in Greece via the aquarium trade. Cent. Eur. J. Biol., 9, 11-18.

Patoka J., Kalous L. and Kopecký O., 2014a. Risk assessment of the crayfish pet trade based on data from the Czech Republic. Biol. Invasions, 16, 2489-2494.

Patoka J., Petrtýl M. and Kalous L., 2014b. Garden ponds as potential introduction pathway of ornamental crayfish. Knowl. Manag. Aquat. Ecosyst., 414, 13.

Patoka J., Kalous L. and Kopecký O., 2015. Imports of ornamental crayfish: the first decade from the Czech Republic's perspective. Knowl. Manag. Aquat. Ecosyst., 416, 04.

Perdikaris C., Kozák P., Kouba A., Konstantinidis E. and Paschos I., 2012. Socio-economic drivers and non-indigenous freshwater crayfish species in Europe. Knowl. Manag. Aquat. Ecosyst., 404, 01.

Rhyne A.L., Tlusty M.F., Schofield P.J., Kaufman L., Morris J.A., Jr. and Bruckner A.W., 2012. Revealing the appetite of the marine aquarium fish trade: the volume and biodiversity of fish imported into the United States. PLOS ONE, 7, e35808. 
Richman N.I., Böhm M., Adams S.B., Alvarez F., Bergey E.A., Bunn J.J.S., Burnham Q., Cordeiro J., Coughran J., Crandall K.A., Dawkins K.L., DiStefano R.J., Doran N.E., Edsman L., Eversole A.G., Füreder L., Furse J.M., Gherardi F., Hamr P., Holdich D.M., Horwitz P., Johnston K., Jones C.M., Jones J.P.G., Jones R.L., Jones T.G., Kawai T., Lawler S., López-Mejía M., Miller R.M., PedrazaLara C., Reynolds J.D., Richardson A.M.M., Schultz M.B., Schuster G.A., Sibley P.J., SoutyGrosset C., Taylor C.A., Thoma R.F., Walls J., Walsh T.S. and Collen B., 2015. Multiple drivers of decline in the global status of freshwater crayfish (Decapoda: Astacidea). Philos. Trans. R. Soc. Lond., B, 370, 20140060.

Scholtz G., Braband A., Tolley L., Reimann A., Mittmann B., Lukhaup C., Steuerwald F. and Vogt G., 2003. Parthenogenesis in an outsider crayfish. Nature, 421, 806-806.

Schuster G.A., Adams S. and Taylor C.A., 2010. Orconectes acares. The IUCN Red List of Threatened Species, http://www.iucnredlist.org/details/153902/0.

Soes M. and Koese B., 2010. Invasive freshwater crayfish in the Netherlands: a preliminary risk analysis. Ministery of Agriculture, Nature and Food Quality, Leiden, The Netherlands, 69.

Strecker A.L., Campbell P.M. and Olden J.D., 2011. The aquarium trade as an invasion pathway in the Pacific Northwest. Fisheries, 36, 74-85.

Taylor C.A., Schuster G.A., Cooper J.E., DiStefano R.J., Eversole A.G., Hamr P., Hobbs H.H., III, Robison H.W., Skelton C.E. and Thoma R.F., 2007. A reassessment of the conservation status of crayfishes of the United States and Canada after 10+ years of increased awareness. Fisheries, 32, 372-389.

Turkmen G. and Karadal O., 2012. The survey of the imported freshwater Decapod species via the ornamental aquarium trade in Turkey. J. Anim. Vet. Adv., 11, 2824-2827.

Vogt G., 2008. The marbled crayfish: a new model organism for research on development, epigenetics and evolutionary biology. J. Zool., 276, 1-13.

Vogt G., 2011. Marmorkrebs: natural crayfish clone as emerging model for various biological disciplines. J. Biosci., 36, 377-382.

Cite this article as: Z. Faulkes, 2015. Marmorkrebs (Procambarus fallax f. virginalis) are the most popular crayfish in the North American pet trade. Knowl. Manag. Aquat. Ecosyst., 416, 20. 